\title{
Kajian Kualitas Produk Susu Pasteurisasi Hasil Penerapan Rantai Pendingin
}

\author{
Z. Wulandari ${ }^{1)}$, E. Taufik ${ }^{1)}$ dan M. Syarif ${ }^{2)}$ \\ ${ }^{1)}$ Departemen Ilmu Produksi dan Teknologi Peternakan, Fakultas Peternakan, Institut Pertanian Bogor \\ ${ }^{2}$ Alumni Departemen Ilmu Produksi dan Teknologi Peternakan, Fakultas Peternakan, Institut Pertanian Bogor
}

\begin{abstract}
The production chain of fresh milk pasteurized milk with different quality of cold chain has an influence on physicochemical and microbiological quality. The objective of this study is to assessment the quality of pasteurized milk products as results of applying the cold chain. The research was conducted on pasteurized milk production chain from farm to consumer consisting of dairy farms of Cibungbulang Livestock Business Area (KUNAK), milk processing unit of SUA Fapet, and street food outlet. Analysis of the quality of fresh milk and pasteurized milk include physicochemical analyzes such as $\mathbf{p H}$, density, fat, protein, dry matter, and nonfat dry matter as well as microbiological quality analyzes such as Total Plate Count, Escherichia coli, and Staphylococcus aureus. It can be concluded that physicochemical qualities include $\mathrm{pH}$, specific gravity, fat, protein, dry matter, and nonfat dry matter and microbiological quality including Total Plate Count, Escheriachia coli and Staphylococcus aureus influenced by production chains with different cold chain quality $(P<0.05)$.
\end{abstract}

Keywords: Cold chain, fresh milk, milk physico-chemical quality, microbiological quality, pasteurized milk.

\section{PENDAHULUAN}

Permintaan susu tumbuh sangat pesat, konsumsi susu segar nasional tahun 2017 berkisar di 16,7 $\mathrm{L} \mathrm{kapita}^{-1}$ tahun $^{-1}$ (BPS 2017). Angka tersebut masih perlu ditingkatkan lagi jika dibandingkan dengan negara tetangga seperti Malaysia 36,2 L kapita $^{-1}$ tahun $^{-1}$, Myanmar 26,7 L kapita ${ }^{-1}$ tahun $^{-1}$, Thailand 22,2 $\mathrm{L}_{\text {kapita }}{ }^{-1}$ tahun $^{-1}$, Filipina mencapai 17,8 L kapita $^{-1}$ tahun $^{-1}$. Produksi susu segar nasional selama periode 2013-2016 yaitu, 786.849 ton, 800.749 ton, 835.125 ton, dan 852.951 ton dengan rata-rata peningkatan produksi sebesar $2,73 \%$ (BPS 2017). Selama periode 2012-2016 produksi susu segar nasional hanya mampu memenuhi kebutuhan susu nasional sebesar 20,07\% saja, sedangkan sebanyak $79,93 \%$ dipenuhi dari impor. Kesadaran masyarakat untuk mengkonsumsi susu cair olahan perlu ditingkatkan agar terus memaksimalkan serapan produksi susu nasional. Saat ini produksi susu olahan segar cair, baik dalam bentuk UHT (Ultra High Temperature) maupun susu pasteurisasi masih sedikit. Industri pengolahan susu dalam negeri lebih suka memproduksi susu bubuk yang bahan bakunya lebih banyak dipasok dari impor (Kementan 2016).

Susu pasteurisasi menurut SNI 01-3951-1995 adalah susu yang telah mengalami proses pemanasan pada temperatur $72{ }^{\circ} \mathrm{C}$ minimum selama 15 detik atau pemanasan pada $63-66^{\circ} \mathrm{C}$ selama 30 menit, kemudian segera didinginkan sampai $10^{\circ} \mathrm{C}$, selanjutnya diperlakukan secara aseptik dan disimpan pada suhu maksimum $4,4{ }^{\circ} \mathrm{C}$ (BSN 1995). Proses penanganan, pengolahan, pengawetan, dan penyimpanan bahan pangan yang kurang baik dapat mengakibatkan susu mudah rusak. Kontaminasi mikroorganisme seperti Staphylococcus aureus ke dalam susu tidak menyebabkan perubahan fisik susu, sehingga keberadaannya tidak disadari konsumen. Selain itu mikroorganisme yang sering digunakan sebagai indikator sanitasi dalam pangan yaitu Escherichia coli. Adanya E. coli di dalam suatu makanan menunjukkan telah terjadi kontaminasi karena sanitasi yang tidak baik selama persiapan produk maupun pengolahan. Spora mikroorganisme patogen tidak hilang oleh proses pasteurisasi, oleh karena itu upaya untuk menjaga kualitas susu pasteurisasi dengan menyimpannya dalam suhu rendah (Hutagaol 2013).

Satuan Usaha Akademik (SUA) Fapet merupakan salah satu unit usaha pengolahan susu milik Fakultas Peternakan, Institut Pertanian Bogor. Salah satu produk susu olahannya adalah susu pasteurisasi. Peternakan sapi perah Kawasan Usaha Peternakan (KUNAK) sapi perah di Cibungbulang merupakan pemasok susu unit usaha SUA Fapet. Hasil olahan susu pasteurisasi salah satunya digunakan sebagai bahan baku outlet milkshake kaki lima yang ditambahkan beberapa bahan lain. Penerapan rantai pendingin merupakan hal yang penting dilakukan pada rantai produksi untuk menjamin kualitas dan keamanan produk susu pasteurisasi yang dihasilkan, karena inspeksi produk akhir saja tidak dapat menjamin kualitas atas keamanan pangan secara keseluruhan. Penelitian ini bertujuan untuk mengkaji kualitas produk susu pasteurisasi hasil penerapan rantai pendingin pada rantai produksi SUA Fapet. 


\section{MATERI DAN METODE}

\section{Tempat dan Waktu Penelitian}

Penelitian telah dilakukan selama 4 bulan yaitu dari bulan Maret hingga bulan Juni 2017. Lokasi penelitian dilakukan di peternakan sapi perah Kawasan Usaha Peternakan (KUNAK) Cibungbulang, SUA Fapet, Laboratorium Ternak Perah, Laboratorium Mikrobiologi, Laboratorium Terpadu Departemen Ilmu Produksi dan Teknologi Peternakan, dan kantin Fakultas Peternakan, Institut Pertanian Bogor.

\section{Bahan}

Beberapa bahan yang digunakan dalam penelitian yaitu sampel susu segar peternakan sapi perah Kawasan Usaha Peternakan (KUNAK) Cibungbulang, susu segar bahan baku, susu pasteurisasi, dan stok susu pasteurisasi SUA Fapet serta milkshake produksi awal dan akhir outlet kaki lima. Bahan yang digunakan untuk analisa kualitas susu adalah fenolftalein, kalium oksalat, $\mathrm{H}_{2} \mathrm{SO}_{4}$, amilakohol, formaldehide, $\mathrm{NaOH}$ 0,1 N, Buffer Peptone Water (BPW), Plate Count Agar (PCA), Eosyn Methylen Blue Agar (EMBA), Baird Parker Agar (BPA), tellurite, kuning telur steril, $\mathrm{NaCl}$ 0,3\%, dry ice, dan akuades.

\section{Alat}

Beberapa alat yang digunakan pada penelitian yaitu coolbox, laminar air flow, magnetic stirrer, waterbath, autoclave, homogeniger (Vortex), colony counter (Quebec, Jepang), milko tester (Master Pro, Bulgaria), lactodensimeter, butirometer, sentrifuge, hot plate, bunsen, $\mathrm{pH}$ meter, cawan Petri, tabung reaksi, erlenmayer, botol jin, botol scot, gelas ukur, oven, inkubator, pipet mikro, tip, timbangan sartorius, alumunium foil, plastik HDPE, plastic wrap, termometer digital, sarung tangan, penutup kepala, dan masker.

\section{Prosedur}

Kegiatan yang dilakukan selama penelitian ini terdiri atas analisis kualitas fisikokimia dan mikrobiologi. Analisis peubah dilakukan sepanjang rantai produksi yang sama yaitu mulai susu segar peternakan sapi perah KUNAK Cibungbulang, susu segar bahan baku, susu pasteurisasi, dan stok susu pasteurisasi SUA Fapet sampai dengan milkshake produksi awal dan akhir outlet kaki lima. Selain itu, dilakukan juga pengukuran suhu susu di setiap titik yang ditentukan.

\section{Uji pH Menurut SNI 01-2782-1998 (BSN 1998)}

Uji Berat Jenis Menurut SNI 01-2782-1998 (BSN 1998; Milkotester 2017)

Pengujian susu segar dan susu pasteurisasi dilakukan dengan alat Master Pro milko tester. Sampel sebanyak 50 mL dimasukkan ke dalam gelas ukur kemudian diuji dengan Master Pro milko tester (Milkotester 2017).

Uji Kadar Protein Metode Titrasi Formol (AOAC 2005; Milkotester 2017)

Pengujian susu segar dan susu pasteurisasi menggunakan alat Master Pro milko tester. Sampel sebanyak $50 \mathrm{~mL}$ dimasukkan ke dalam gelas ukur kemudian diuji dengan Master Pro milko tester (Milkotester 2017).
Uji Kadar Lemak Metode Gerber Menurut SNI 012782-1998 (BSN 1998; Milkotester 2017)

Pengujian susu segar dan susu pasteurisasi menggunakan alat Master Pro milko tester. Sampel sebanyak $50 \mathrm{~mL}$ dimasukkan ke dalam gelas ukur kemudian diuji dengan Master Pro milko tester (Milkotester 2017).

Uji Bahan Kering Menurut SNI 01-2782-1998 (BSN 1998)

Bahan kering dapat dihitung dengan menggunakan rumus Fleischman, dengan rumus sebagai berikut.

Bahan kering $=1,23 \mathrm{~L}+2,71 \frac{100(\mathrm{BJ}-1)}{\mathrm{BJ}}$

$\mathrm{L} \quad=$ kadar lemak (\%); dan

BJ = berat jenis pada $27,5^{\circ} \mathrm{C}$.

Uji Bahan Kering Tanpa Lemak Menurut SNI 01-27821998 (BSN 1998)

Bahan kering tanpa lemak dihitung dengan mengurangi kadar bahan kering dengan kadar lemak.

Analisis Total Plate Count (Pelczar dan Chan 2007; BAM 2001)

Analisis Kuantitatif Escherichia coli (Modifikasi Pelczar dan Chan 2007; BAM 2001)

Analisis Kuantitatif Staphylococcus aureus (Pelczar dan Chan 2007; BAM 2001)

\section{Analisis Data dan Rancangan Percobaan}

Data penelitian dikoleksi kemudian dianalisis ragam (ANOVA) berdasarkan rancangan acak kelompok untuk semua peubah yang diamati. Faktor independennya yaitu titik rantai produksi (P1: susu segar peternakan sapi perah KUNAK; P2: susu segar SUA Fapet; P3: susu pasteurisasi SUA Fapet, P4: stok susu pasteurisasi SUA Fapet; P5: milkshake outlet kaki lima produksi awal; P6: milkshake outlet kaki lima produksi akhir). Sampel yang digunakan merupakan 1 rantai produksi. Penelitian dikelompokkan berdasarkan periode waktu pengambilan sampel (minggu pertama, minggu kedua dan minggu ketiga). Jika faktor independen berpengaruh nyata dilanjutkan dengan uji Tukey. Model linear yang digunakan sebagai berikut (Gasperz 1991).

$$
Y i j=\mu+A i+B j+\varepsilon i j
$$

Yij : Nilai hasil penelitian pada respon faktor independen titik rantai produksi ke-i (P1: susu segar peternakan sapi perah KUNAK; P2: susu segar SUA Fapet; P3: susu pasteurisasi SUA Fapet, P4: stok susu pasteurisasi SUA Fapet; P5: milkshake outlet kaki lima produksi awal; P6: milkshake outlet kaki lima produksi akhir) dan periode pengambilan sampel ke-j (minggu pertama, minggu kedua, dan minggu ketiga);

$\mu \quad$ : Nilai rata-rata penelitian pada respon faktor independen; 
: Pengaruh faktor independen titik rantai produksi ke-i (P1: susu segar dari peternakan sapi perah KUNAK; P2: susu segar SUA Fapet; P3: susu pasteurisasi SUA Fapet, P4: stock susu pasteurisasi SUA Fapet; P5: milkshake outlet kaki lima produksi awal; P6: milkshake outlet kaki lima produksi akhir);

Bj : Pengaruh kelompok periode pengambilan sampel ke-j (minggu pertama, minggu kedua, dan minggu ketiga); dan

cij : Pengaruh galat percobaan dari faktor independen titik rantai produksi ke-i (P1: susu segar peternakan sapi perah KUNAK; P2: susu segar SUA Fapet; P3: susu pasteurisasi SUA Fapet, P4: stock susu pasteurisasi SUA Fapet; P5: milkshake outlet kaki lima produksi awal; P6: milkshake outlet kaki lima produksi akhir) dan periode pengambilan sampel ke-j (minggu pertama, minggu kedua, dan minggu ketiga).

\section{HASIL DAN PEMBAHASAN}

\section{Kualitas Fisikokimia}

Hasil penelitian kualitas fisikokimia susu segar, susu pasteurisasi, dan milkshake pada rantai produksi dapat dilihat pada Tabel 1 dan Tabel 2. Hasil penelitian menunjukan bahwa faktor independen titik rantai produksi memberikan pengaruh nyata $(\mathrm{P}<0,05)$ terhadap kualitas fisikokimia.

Nilai pH susu segar berdasarkan SNI 3141.1:2011 yaitu 6,3 sampai dengan 6,8 (BSN 2011). Hasil penelitian terhadap nilai $\mathrm{pH}$ susu segar yang didapat dari peternakan sapi perah KUNAK dan bahan baku SUA Fapet sesuai dengan SNI 3141.1:2011. Selama perjalanan dari tempat pemerahan sapi sampai di SUA Fapet terjadi peningkatan nilai $\mathrm{pH}$ susu segar, hal ini disebabkan peningkatan nilai TPC dan bakteri patogen lainnya sehingga meningkatkan nilai pH (Winarno dan Fernandez 2007). Susu pasteurisasi juga mengalami peningkatan nilai $\mathrm{pH}$ dibandingkan susu segar diduga akibat aktivitas mikroorganisme yang tahan

Tabel 1. Rataan kualitas fisik susu segar dan produk susu pasteurisasi pada rantai produksi

\begin{tabular}{ccc}
\hline Sampel & \multicolumn{2}{c}{ Parameter } \\
\cline { 2 - 3 } & $\mathrm{pH}$ & Berat Jenis $\left(\mathrm{g} \mathrm{mL}^{-3}\right)$ \\
\hline P1 & $6,60 \pm 0,01 \mathrm{c}$ & $1,0233 \pm 0,0007 \mathrm{c}$ \\
P2 & $6,69 \pm 0,04 \mathrm{~b}$ & $1,0226 \pm 0,0008 \mathrm{c}$ \\
P3 & $6,78 \pm 0,01 \mathrm{a}$ & $1,0235 \pm 0,0032 \mathrm{c}$ \\
P4 & $6,80 \pm 0,01 \mathrm{a}$ & $1,0224 \pm 0,0038 \mathrm{c}$ \\
P5 & $6,75 \pm 0,11 \mathrm{ab}$ & $1,0450 \pm 0,0000 \mathrm{~b}$ \\
P6 & $6,73 \pm 0,07 \mathrm{ab}$ & $1,0500 \pm 0,0000 \mathrm{a}$ \\
\hline
\end{tabular}

Keterangan: Angka dengan huruf yang berbeda pada kolom yang sama menunjukkan perbedaan yang nyata $(\mathrm{P}<0,05)$, P1: susu segar peternakan sapi perah KUNAK; P2: susu segar SUA Fapet; P3: susu pasteurisasi SUA Fapet, P4: stock susu pasteurisasi SUA Fapet; P5: milkshake outlet kaki lima produksi awal; P6: milkshake outlet kaki lima produksi akhir. suhu, karena proses pasteurisasi tidak menghilangkan seluruh mikroorganisme patogen dalam susu sehingga mempengaruhi nilai $\mathrm{pH}$ susu pasteurisasi. Nilai $\mathrm{pH}$ milkshake mengalami penurunan disebabkan adanya penambahan bahan lain sebagai komposisi dan perasa serta peningkatan bakteri asam laktat yang dapat menurunkan $\mathrm{pH}$ susu (Susilorini dan Sawitri 2006).

Berat jenis susu segar menurut SNI 3141.1:2011 adalah $1.027 \mathrm{~g} \mathrm{~mL}^{-3}$ (BSN 2011). Hasil penelitian terhadap berat jenis susu segar di bawah rataan standar, yaitu $1,0233 \pm 0,0007 \mathrm{~g} \mathrm{~mL}^{-3}$ dan $1,0226 \pm 0,0008 \mathrm{~g} \mathrm{~mL}^{-3}$. Hal ini diduga susu tercampur dengan air sehingga susu lebih encer. Penambahan air pada susu dapat menurunkan berat jenis susu (Gregory et al. 2007). Rachmawan (2001) menyatakan bahwa semakin besar berat jenis pada susu maka semakin bagus karena kandungan dari susu tersebut masih pekat, persentase bahan padat bukan lemak tinggi, dan kadar air dalam susu lebih rendah, sedangkan semakin banyak lemak pada susu maka semakin rendah berat jenisnya. Variasi berat jenis terjadi karena perbedaan besarnya kandungan lemak, laktosa, protein, dan garam mineral dalam susu (Mukhtar 2006). Berat jenis susu mengalami kenaikan yang nyata $(\mathrm{P}<0,05)$ pada milkshake disebabkan adanya penambahan bahan tambahan dan perasa pada pengolahan milkshake. Pengujian berat jenis sangat dipengaruhi oleh total solid yang terkandung dalam susu, antara lain berat jenis protein dan berat jenis laktosa. Berat jenis milkshake selain dipengaruhi kandungan protein dan laktosa susu juga dipengaruhi oleh berat jenis gula yang ditambahkan dalam proses pembuatan milkshake (Susilorini dan Sawitri 2006).

Berdasarkan Tabel 2 terlihat bahwa kandungan protein susu segar dan produk susu pasteurisasi sesuai dengan SNI 3141.1:2011 (BSN 2011) dan SNI 01-39511995 (BSN 1995), yaitu minimum 2,8\% dan 2,5\%. Nilai kadar protein susu pasteurisasi lebih rendah $(\mathrm{P}<0,05)$ dari susu segar akibat adanya proses pemanasan. Penambahan biskuit oreo sebesar $10 \%$ pada proses pengolahan menjadi milkshake dapat meningkatkan secara nyata $(\mathrm{P}<0,05)$ nilai kadar protein. Hal ini disebabkan oleh biskuit yang digunakan mengandung glutein yang terdiri atas sukrosa dan protein.

Tabel 2 menunjukkan bahwa nilai kadar lemak susu segar sesuai dengan SNI 3141.1:2011 (BSN 2011) dan SNI 01-3951-1995 (BSN 1995), yaitu minimum 3\% untuk susu segar, 2,8\% untuk susu pasteurisasi tanpa cita rasa dan $1.5 \%$ untuk susu pasteurisasi dengan cita rasa. Nilai kadar lemak susu segar dipengaruhi oleh beberapa faktor diantaranya bangsa sapi, pakan, dan interval pemerahan (Kurniawan et al. 2012), sedangkan kadar lemak susu pasteurisasi dan milkshake ditentukan oleh bahan baku dan ketepatan proses pengolahan (Susilorini dan Sawitri 2006). Nilai kadar lemak mengalami penurunan secara nyata $(\mathrm{P}<0,05)$ setelah proses pengolahan milkshake, hal ini berkebalikan dengan nilai kadar proteinnya karena perasa yang ditambahkan didominasi oleh glutein.

Bahan kering merupakan komponen susu selain air yang meliputi lemak, protein, laktosa, dan mineral, sedangkan bahan kering tanpa lemak yaitu selisih antara bahan kering dan kadar lemak susu (Vergi et al. 2015). 
Wulandari et al.

Jurnal Ilmu Produksi dan Teknologi Hasil Peternakan 5 (3): 94-100

Tabel 2. Rataan kualitas kimia susu segar dan produk susu pasteurisasi pada rantai produksi

\begin{tabular}{ccccc}
\hline Sampel & $\mathrm{P}$ & $\mathrm{L}$ & $\mathrm{BK}$ & $\mathrm{BKTL}$ \\
\cline { 2 - 5 } & $(\%)$ & $(\%)$ & $(\%)$ & $(\%)$ \\
\hline P1 & $3,07 \pm 0,10 \mathrm{~b}$ & $4,42 \pm 0,18 \mathrm{a}$ & $11,59 \pm 0,39 \mathrm{c}$ & $7,18 \pm 0,22 \mathrm{c}$ \\
P2 & $2,95 \pm 0,10 \mathrm{~b}$ & $3,58 \pm 0,23 \mathrm{~b}$ & $10,39 \pm 0,48 \mathrm{~d}$ & $6,80 \pm 0,25 \mathrm{c}$ \\
P3 & $2,67 \pm 0,10 \mathrm{c}$ & $3,37 \pm 0,47 \mathrm{~b}$ & $10,37 \pm 0,99 \mathrm{~d}$ & $7,00 \pm 0,82 \mathrm{c}$ \\
P4 & $2,67 \pm 0,10 \mathrm{c}$ & $3,27 \pm 0,50 \mathrm{~b}$ & $9,95 \pm 0,76 \mathrm{~d}$ & $6,68 \pm 0,91 \mathrm{c}$ \\
P5 & $3,74 \pm 0,13 \mathrm{a}$ & $1,93 \pm 0,47 \mathrm{c}$ & $14,05 \pm 0,58 \mathrm{~b}$ & $12,11 \pm 0,11 \mathrm{~b}$ \\
P6 & $3,54 \pm 0,51 \mathrm{a}$ & $1,96 \pm 0,04 \mathrm{c}$ & $15,31 \pm 0,04 \mathrm{a}$ & $13,35 \pm 0,01 \mathrm{a}$ \\
\hline
\end{tabular}

Keterangan: Angka dengan huruf yang berbeda pada kolom yang sama menunjukkan perbedaan yang nyata $(\mathrm{P}<0,05)$. $\mathrm{P}:$ protein; $\mathrm{L}$ : lemak; BK: bahan kering; dan BKTL: bahan kering tanpa lemak. P1: susu segar peternakan sapi perah KUNAK; P2: susu segar SUA Fapet; P3: susu pasteurisasi SUA Fapet, P4: stock susu pasteurisasi SUA Fapet; P5: milkshake outlet kaki lima produksi awal; P6: milkshake outlet kaki lima produksi akhir.

Nilai bahan kering dan bahan kering tanpa lemak susu segar berdasarkan SNI 3141.1:2011 yaitu 10,8 dan 7,8 (BSN 2011), sedangkan bahan kering dan bahan kering tanpa lemak susu pasteurisasi tanpa rasa serta dengan rasa berdasarkan SNI 01-3951-1995 yaitu 10,5 dan 7,7 serta 9,0 dan 7,5 (BSN 1995). Nilai bahan kering dan bahan kering tanpa lemak berdasarkan pengamatan hanya milkshake yang memenuhi standar SNI. Banyak faktor yang dapat mempengaruhi bahan kering susu diantaranya pakan, penyakit, umur, masa laktasi, dan musim (Wibowo et al. 2013). Proses pasteurisasi secara nyata $(\mathrm{P}<0,05)$ menurunkan kadar protein dan lemak susu. Hal ini sebanding dengan bahan kering dan bahan kering tanpa lemak mengalami penurunan yang nyata $(\mathrm{P}<0,05)$ karena sangat bergantung pada komponen tersebut. Pada proses pengolahan milkshake ditambahkan beberapa bahan lain seperti perasa oreo, gula, dan es batu. Hal ini dapat meningkatkan secara nyata $(\mathrm{P}<0,05)$ nilai berat jenis, protein, bahan kering, dan bahan kering tanpa lemak pada milkshake dibandingkan dengan susu segar dan susu pasteurisasi.

\section{Kualitas Mikrobiologi}

Hasil penelitian kualitas mikrobiologi susu segar, susu pasteurisasi, dan milkshake pada rantai produksi dapat dilihat pada Tabel 3. Hasil menunjukan bahwa faktor independen titik rantai produksi memberikan pengaruh nyata $(\mathrm{P}<0,05)$ terhadap kualitas mikrobiologi.

Pasteurisasi umumnya dilakukan melalui suatu heat exchanger (Scott 2006). Pasteurisasi dapat dilakukan pada suhu $72-75{ }^{\circ} \mathrm{C}$ selama 15 detik (high temperature short time) atau $63-65{ }^{\circ} \mathrm{C}$ selama 30 menit (low temperature long time). Metode pasteurisasi yang sering dan umum digunakan adalah high temperature short time (HTST) dengan pemanasan pada suhu $72-75{ }^{\circ} \mathrm{C}$ selama 15 detik, karena susu dengan cepat mengalir melalui heat exchanger. Metode pasteurisasi yang digunakan oleh SUA Fapet yaitu modifikasi metode HTST. Selanjutnya susu dengan cepat didinginkan hingga suhu di bawah $10{ }^{\circ} \mathrm{C}$ untuk mencegah mikroorganisme patogen yang tahan pemanasan menjadi aktif kembali. Pengemasan sebaiknya dilakukan dengan segera secara aseptis setelah suhu dingin di bawah 10 ${ }^{\circ} \mathrm{C}$ tercapai, dalam wadah yang tertutup rapat untuk menghindari terjadinya kontaminasi dan pencemaran dari luar dan harus disimpan dalam pendingin (Murdiati 2004).
Tabel 3 menunjukkan bahwa nilai TPC, Escherichia coli dan Staphylococcus aureus dipengaruhi secara nyata $(\mathrm{P}<0,05)$ oleh faktor independen titik rantai produksi. Secara statistik nilai TPC susu segar KUNAK (P1) dan susu segar bahan baku SUA Fapet (P2) tidak berbeda nyata, yaitu sebesar 5,70 $\pm 0,53$ dan 6,43 $\pm 0,68 \log$ cfu $\mathrm{mL}^{-1}$. P1 memenuhi kriteria standar nilai TPC susu segar menurut BSN (2011) dalam SNI 01-6366-2000 yaitu kurang dari sama dengan 6 $\log$ cfu $\mathrm{mL}^{-1}$, sedangkan P2 melebihi batas yang ditentukan BSN akibat proses distribusi susu yang tidak berpendingin. Menurut Oliver et al. (2005) jumlah mikroorganisme yang terdapat pada susu segar dipengaruhi oleh beberapa faktor, seperti ukuran kandang, jumlah hewan, higiene dan sanitasi, praktek manajemen, letak geografi, musim, perbedaan metode deteksi dan variasi sampel. Menurut Magadan (2010) pencemaran mikroorganisme pada susu segar dapat disebabkan oleh kontaminasi tanah, air, udara, pupuk kandang, debu, peralatan, dan pekerja. Menurut Wicaksono dan Sudarwanto (2016) intervensi penyuluhan dan pendampingan kepada peternak skala kecil sangat penting untuk meningkatkan kualitas susu.

Penurunan nilai TPC secara nyata $(\mathrm{P}<0,05)$ menjadi $1,48 \pm 0,37 \log \mathrm{cfu} \mathrm{mL}^{-1}$ terjadi setelah susu segar dipasteurisasi dapat dilihat pada Gambar 2. Nilai TPC susu pasteurisasi sesuai dengan BSN (1995) dalam SNI 016366-2000 yaitu kurang dari sama dengan $4 \log \mathrm{cfu} \mathrm{mL}^{-1}$. Menurut Scott (2006) proses pasteurisasi dapat mengurangi jumlah mikroorganisme yang sebelumnya terdapat pada susu segar. Nilai TPC susu pasteurisasi mengalami kenaikan tidak signifikan selama penyimpanan, namun peningkatan nilai TPC selama penyimpanan berpendingin mengindikasikan bahwa mikroorganisme masih dapat tumbuh selama penyimpanan dalam pendingin. Banyaknya jumlah mikroorganisme dalam susu pasteurisasi selama penyimpanan berpendingin diduga akibat pertumbuhan bakteri yang tahan terhadap suhu pasteurisasi. Jenis dan jumlah bakteri tersebut tergantung pada populasi mikroba susu segar dan bahan baku lainnya seperti gula, kesempurnaan proses pasteurisasi, pengemasan sampai kecepatan penyimpanan di pendingin (Jay 1999).

Kenaikan nilai TPC tertinggi terjadi saat susu pasteurisasi diolah menjadi milkshake diduga karena rantai pendingin yang tidak stabil, higiene pekerja, sanitasi 
Tabel 3. Rataan kualitas mikrobiologi susu segar dan produk susu pasteurisasi pada rantai produksi

\begin{tabular}{cccc}
\hline Sampel & $\begin{array}{c}\text { Total Plate } \\
\text { Count }\end{array}$ & Escherichia coli & $\begin{array}{c}\text { Staphylococcus } \\
\text { aureus }\end{array}$ \\
\cline { 2 - 4 } & $(\log \mathrm{cfu} \mathrm{mL}-1)$ & $\left(\log \mathrm{cfu} \mathrm{mL} \mathrm{m}^{-1}\right)$ & (log cfu mL $\left.^{-1}\right)$ \\
\hline P1 & $5,70 \pm 0,53 \mathrm{a}$ & $2,66 \pm 0,19 \mathrm{a}$ & $3,37 \pm 0,39 \mathrm{a}$ \\
P2 & $6,43 \pm 0,68 \mathrm{a}$ & $3,10 \pm 0,71 \mathrm{a}$ & $4,06 \pm 0,31 \mathrm{a}$ \\
P3 & $1,48 \pm 0,37 \mathrm{~b}$ & $0,00 \pm 0,00 \mathrm{~b}$ & $0,00 \pm 0,00 \mathrm{c}$ \\
P4 & $2,01 \pm 0,55 \mathrm{~b}$ & $0,72 \pm 0,87 \mathrm{~b}$ & $0,49 \pm 0,85 \mathrm{c}$ \\
P5 & $5,17 \pm 0,50 \mathrm{a}$ & $2,58 \pm 0,06 \mathrm{a}$ & $1,52 \pm 1,33 \mathrm{bc}$ \\
P6 & $5,74 \pm 1,01 \mathrm{a}$ & $2,61 \pm 0,04 \mathrm{a}$ & $2,42 \pm 0,79 \mathrm{ab}$ \\
\hline
\end{tabular}

Keterangan: Angka dengan huruf yang berbeda pada kolom yang sama menunjukkan perbedaan yang nyata $(\mathrm{P}<0,05)$.

peralatan, dan penambahan berbagai bahan tambahan dan perasa. Menurut Supardi (1999) penambahan bahan tambahan lain pada pembuatan suatu produk pangan dapat mempengaruhi kualitas mikrobiologi produk tersebut. Kenaikan nilai TPC terjadi sampai dengan $5 \log \mathrm{cfu} \mathrm{mL}^{-1}$ ini di atas batas maksimal yang ditentukan oleh SNI susu pasteurisasi. Menurut Murdiati et al. (2004) upaya yang dapat dilakukan untuk memperbaiki kualitas mikrobiologi susu pasteurisasi dengan mempertahankan kualitas rantai pendingin produk dan tata laksana produksi yang baik dan benar.

Berdasarkan BSN (2000) dalam SNI 01-6366-2000 tentang Batas Maksimum Cemaran Mikroba dan Batas Maksimum Residu dalam Bahan Makanan Asal Hewan nilai Escherichia coli baik pada susu segar maupun susu pasteurisasi harus nol atau tidak ada. Berdasarkan hasil penelitian nilai E. coli cukup tinggi (Tabel 2). Tingginya pencemaran $E$. coli pada susu segar dapat disebabkan oleh adanya kontaminasi yang berasal dari air yang digunakan dalam peternakan. Menurut Manning (2010) air yang terkontaminasi koliform merupakan sumber pencemaran yang paling penting di sebuah peternakan karena bakteri ini dapat bertahan hidup dalam sedimen air selama enam bulan, bahkan dapat bertahan hidup sepanjang musim dingin. Selain itu, air yang telah terkontaminasi dapat bercampur dengan air tanah dan menjadi sumber penularan di lingkungan sekitar. Jarak peternakan yang dekat dengan pemukiman juga dapat menjadi faktor yang menyebabkan tingginya kontaminasi E. coli. Hal tersebut dapat meningkatkan penyebaran dan kontaminasi pada air yang berasal dari pembuangan dan penampungan kotoran manusia yang dekat dengan sumber air pada peternakan (Winarno 1993). Tingginya jumlah kontaminasi E. coli pada susu segar menunjukkan adanya tingkat pencemaran fekal yang tinggi. Hal ini disebabkan karena koliform merupakan mikroflora yang hidup pada saluran pencernaan makhluk hidup berdarah panas dan dapat berada di lingkungan melalui feses (Sperling 2007).

Menurut Sarinengsih (2009) proses pasteurisasi membunuh bakteri patogen, ragi, jamur dan sebagian besar sel vegetatif pada bakteri. Proses pasteurisasi secara nyata $(\mathrm{P}<0,05)$ dapat menurunkan nilai TPC, E. coli, dan $S$. aureus pada susu (Tabel 2). Hal serupa juga dilaporkan oleh
Hutagaol (2013) bahwa proses pasteurisasi efektif dalam mengurangi nilai TPC, koliform, dan S. aureus. Faktor lain yang dapat menimbulkan kontaminasi $E$. coli pada susu pasca pasteurisasi yaitu kesalahan dalam penanganan susu. Menurut Sarinengsih (2009) bakteri yang tahan terhadap suhu pasteurisasi seperti mesofil dan thermofil yang dapat melakukan kerusakan selanjutnya pada susu. Penyimpanan susu yang tidak menggunakan rantai pendingin dapat meningkatkan jumlah mikroorganisme selama proses distribusi dan penyimpanan susu (Altalhi dan Hassan 2009).

Batas maksimum cemaran Staphylococcus aureus pada susu segar dan susu pasteurisasi berdasarkan BSN (2000) dalam SNI 01-6366-2000 sebesar 2 dan 1 log cfu $\mathrm{mL}^{-1}$. Rataan nilai cemaran $S$. aureus pada semua sampel memiliki nilai melebihi SNI 01-6366-2000 kecuali pada susu pasteurisasi. Hal ini menunjukkan proses pasteurisasi yang dilakukan secara nyata $(\mathrm{P}<0,05)$ dapat mengurangi jumlah $S$. aureus. Reservoir utama $S$. aureus pada susu segar terdapat dalam ambing/kuartir yang terinfeksi, penyebaran diantara sapi terjadi selama proses pemerahan (Akineden et al. 2001). Kejadian mastitis subklinis sering kali tidak diketahui oleh peternak, karena sapi perah tidak memperlihatkan adanya gejala peradangan atau pembengkakan ambing. Pada umumnya makanan dapat tercemar apabila tidak disimpan pada suhu di bawah 4 ${ }^{\circ} \mathrm{C}$. Kondisi kebersihan peralatan dan penyimpanan yang tidak sesuai kemungkinan besar menyebabkan terjadinya pertumbuhan S. aureus (Cahyono et al. 2013).

Menurut Cretenet et al. (2011) keberadaan S. aureus pada susu dan produk susu menunjukkan praktek higiene personal yang tidak baik dari pekerja saat bekerja, buruknya kebersihan lingkungan sekitar dan adanya penanganan yang tidak tepat oleh pekerja. Secara umum, kontaminasi S. aureus dapat disebabkan oleh adanya kontaminasi yang berasal dari pekerja sehingga bakteri ini bertambah jumlahnya dan menimbulkan pencemaran pada susu. $S$. aureus merupakan bakteri yang hidup secara fakultatif anaerobik pada saluran hidung, tenggorokan, dan kulit hewan dan manusia. Bakteri ini merupakan sumber kontaminasi terbesar ke dalam susu, produk olahan susu, dan bahan pangan lainnya (James et al. 2003).

\section{KESIMPULAN}

Susu segar KUNAK, susu segar dan susu pasteurisasi SUA Fapet, serta milkshake outlet kaki lima hanya memenuhi kualitas $\mathrm{pH}$, kadar protein, dan kadar lemak berdasarkan SNI 3141.1:2011 tentang susu segar dan SNI 01-3951-1995 tentang susu pasteurisasi. Hanya sampel susu pasteurisasi SUA Fapet yang memenuhi kualitas mikrobiologi berdasarkan SNI 01-6366-2000 tentang batas maksimum cemaran mikroba dan batas maksimum residu dalam bahan makanan asal hewan. Proses pasteurisasi yang dilakukan oleh PT D-Farm Agripima sudah efektif untuk mengurangi cemaran mikroba pada susu, sedangkan cemaran pasca pasteurisasi disebabkan oleh penanganan produk yang kurang tepat. 


\section{Saran}

Sebaiknya dilakukan analisis pada susu pasteurisasi di oulet kaki lima sebelum diolah menjadi milkshake. Menambahkan analisis laktosa dan uji mastitis pada penelitian selanjutnya. Perlu dilakukan pembinaan terkait higiene dan sanitasi kepada peternak, pekerja, dan pemilik pabrik. Perlu dilakukan evaluasi dan kontrol terhadap proses penanganan, pengolahan, dan penyimpanan.

\section{DAFTAR PUSTAKA}

Akineden O, Annemuller C, Hasan A, Lammler C, Wolter W, Zschok M. 2001. Toxin genes and other characteristics of Staphylococcus aureus isolates from milk of cow with mastitis. Clinical and Diagnostic Lab Immunol. 8(5): 959-964.

Altalhi AD, Hassan SA. 2009. Bacterial quality of raw milk investigated by Escherichia coli and isolated analysis for specific virulence-gene markers. Food Control (20): 913-917.

[AOAC] Association of Official Analytical Chemist. 2005. Official Method of Analysis of the Association of Official Analytical of Chemist. Arlington (US): The Association of Official Analytical Chemist Inc.

[BAM] Bacteriological Analytical Manual. 2001. Aerobic Plate Count. New York (US): FDA Departement of Health and Human Services.

[BSN] Badan Standardisasi Nasional. 1995. SNI 01-39511995 tentang Susu Pasteurisasi. Jakarta (ID): BSN.

[BSN] Badan Standardisasi Nasional. 1998. SNI 01-27821998 tentang Metode Pengujian Susu Segar. Jakarta (ID): BSN.

[BSN] Badan Standardisasi Nasional. 2000. SNI 01-63662000 tentang Batas Maksimum Cemaran Mikroba dan Batas Maksimum Residu dalam Makanan Asal Hewan. Jakarta (ID): BSN.

[BSN] Badan Standardisasi Nasional. 2011. SNI 3141.1:2011 tentang Susu Segar Bagian-1: Sapi. Jakarta (ID): BSN.

[BPS] Badan Pusat Statistik. 2017. Produksi Susu Segar Menurut Provinsi, 2013-2016. Jakarta (ID): BSN.

Buckle KA, Edwards RA, Fleet GH, Wotton M. 1987. Ilmu Pangan. Adiono dan H Purnomo, penerjemah. Jakarta (ID): UI Pr.

Cahyono D, Padaga MC, Sawitri ME. 2013. Kajian kualitas mikrobiologi (Total Plate Count (TPC), Enterobacteriaceae dan Staphylococcus aureus) susu sapi segar di Kecamatan Krucil Kabupaten Probolinggo. J ITHT. 8(1):1-8.

Cretenet M, Even S, Loir Y. 2011. Unveiling Staphylococcus aureus enterotoxin production in dairy products: a review of recent advances face new challenges. Dairy Sci Technol. 91(24): 127-150.

[DSN] Dewan Standardisasi Nasional. 1987. SNI 01-02081987 tentang Alat-Alat Penanganan Susu: Cooling Unit. Jakarta (ID): DSN.

Gasperz V. 1991. Teknik Analisis dalam Penelitian Percobaan. Bandung (ID): Tarsito.

Gregory DM, Judith KJ, Louis DMB. 2007. Handbook of
Dairy Food and Nutrition. New York (US): CRC Pr.

Hutagaol FVA. 2013. Kualitas mikrobiologi susu sebelum dan sesudah pasteurisasi [skripsi]. Bogor (ID): Institut Pertanian Bogor.

James PS, Daifas DP, El-Khoury W, Austin JW. 2003. Microbial Safety of Minimally Processed Foods. New York (US): CRC Pr.

Jay JM. 1999. Modern Food Microbiology. New York (US): Chapman and Hall.

[Kementan] Kementrian Pertanian. 2016. Outlook Susu, Komoditas Pertanian Subsektor Peternakan 2016. Jakarta (ID): Kementan.

Kurniawan, Indrijani H, Tasripin DS. 2012. Model kurva produksi susu sapi perah dan korelasinya pada pemerahan pagi dan siang periode laktasi satu. Med Pet. 29 (1): 5-46.

Magadan AH. 2010. Handbook of Dairy Foods Analysis. New York (US): CRC Pr.

Manning SD. 2010. Escherichia coli Infections. Philadelphia (US): Chelsea House Pub.

Milkotester. 2017. Operating Instruction Milk Analizing Device: Master Pro [internet]. [diacu 2017 Maret]. Tersedia dari http://www.milkotester.com/data/ Master_Pro.pdf

Mukhtar A. 2006. Ilmu Produksi Ternak Perah. Surakarta (ID): Lembaga Pengembangan Pendidikan (LPP) dan UPT UNS Pr.

Murdiati TB, Priadi A, Rachmawati S, Yuningsih. 2004. Pasteurized milk and implementation of HACCP (Hazard Analysis Critical Control Point). JITV. 9(3): $172-180$.

Oliver SP, Jayarao BM, Almeida RA. 2005. Foodborne pathogens in milk and the dairy farm environment: Food safety and public health implications. Foodborne Pathog. Dis. 2: 115-129.

Ovca A, Jevsnik M. 2009. Maintaining a cold chain from purchase to the home and at home: consumer option. $J$. Food Control 167-172.

Pelczar MJ, Chan ECS. 2007. Dasar-Dasar Mikrobiologi Jilid I. Terjemahan Hadioetomo RS, Imas T, Tjitrosomo SS, Angka SL. Jakarta (ID): Indonesia Pr Foundation.

Rachmawan O. 2001. Penanganan Susu Segar. Jakarta (ID): Departemen Pendidikan Nasional.

Sarinengsih M. 2009. Pengaruh penambahan asam dokosaheksaenoat (DHA) terhadap ketahanan susu pasteurisasi rasa cokelat [skripsi]. Bandung (ID): FMIPA UPI.

Scott MC. 2006. Viability of waste milk pasteurization systems for calf feeding systems [tesis]. Virginia (US): Faculty of Virginia Polytechnic Institute and State University.

Sperling MV. 2007. Biological Wastewater Treatment: Wastewater Characteristics, Treatment and Disposal. London (UK): IWA Pub.

Sudarwanto M, Sudarnika E. 2008. Hubungan antara pH susu dengan jumlah sel somatik sebagai parameter mastitis subklinik. Med Pet. 31(2): 107-113.

Supardi I, Sukamto. 1999. Mikrobiologi 
dalam Pengolahan dan Keamanan Pangan. Jakarta (ID): Gramedia.

Susilorini TE, ME Sawitri. 2006. Produk Olahan Susu. Jakarta (ID): Penebar Swadaya.

Vergie MD, Suprayogi S, Sayuthi SM. 2015. Kandungan lemak, total bahan kering dan bahan kering tanpa lemak susu sapi perah akibat interval pemeliharaan berbeda. Animal Agriculture Journal (5): 195-199.

Wibowo PA, Astuti TY, Soediarto P. 2013. Kajian total solid (TS) dan solid non fat (SNF) susu kambing Peranakan Etawa (PE) pada satu periode laktasi. $J$. Ilmu Peternakan 1(1): 214-221.

Winarno FG, IE Fernandez. 2007. Susu dan Produk Fermentasinya. Bogor (ID): M-Brio Pr. 